\title{
Sustaining Value Creation through Knowledge of Customer Expectations
}

\author{
Hamzat, Bolaji Saheed ${ }^{1}$, Bashiru, Bello², Daramola, Gloria ${ }^{3}$. \\ ${ }^{1,2,3}$ Department of Business Administration, College of Management Sciences, Bells University of Technology, \\ Nigeria
}

\begin{abstract}
As the pursuit of knowledge becomes increasingly central to firms' competitiveness, we argued that knowing what the customer expects of product offerings is a prerequisite for sustaining the delivery of value. Thus, this paper seeks to provide a theoretical contribution to the growing recognition of researches on customer as a source of firms' competence. By building on extant literature of value creation, customer satisfaction/dissatisfaction, and the theories of firm knowledge creation, we proposed a framework of how firms can sustain value creation through knowledge of customer expectations. We argued that sustaining firms' value creation resides in the ability of firms to continuously anticipate, integrate and configure knowledge of customer expectations to create product offerings that meet or exceed customer expectations and generate better economic returns than other competing alternative firms.
\end{abstract}

Keywords: Customer Expectations, Customer Satisfaction/Dissatisfaction, Knowledge of Customer Expectations, Product Offerings, Value creations.

\section{Introduction}

Though, it has long been realised - the importance of customers, never has this importance been more compelling than now. Researches are beginning to recognise the roles of the customers beyond the mere consumer of value but also the source it (Slater and Narver, 1994; Woodruff, 1997; Slater, 1997; Prahalad and Venkatram, 2000). Driven by globalisation and information technology, there is a growing sophistication in customer taste and preference which has led to an increasing number of product alternatives as well as short lifecycle of products. For firms, sustaining competitiveness means they must timely and continuously develop product offerings that can capture these dynamics better than competing alternatives - that is, capture these expectations and translate them into value for the customers.

Examining firms, sustaining value creation resides in the ability to translate what the firms know about the customer expectations into product offerings. It must develop the capability to acquire knowledge of customer expectations (KCE) by deploying sound approaches. Extant literatures and evidence from contemporary high-performing firms point to this direction - knowing what the customer expects of a product offering as a prerequisite to creating value. However, the challenge for firms is how can they translate what they know about customer expectations into value for the customers as well as the firms? And importantly, how can firms sustain the value creation?

This paper therefore examines how firms can sustain the value creation through KCE. Firstly, the paper examines what is value creation in the context of what the firm does. Secondly, through reviews of customer satisfaction/dissatisfaction (CS/D) literatures, the customer expectations and the key sources of these expectations for the firm were identified. Thirdly, using the theory of firm knowledge creation, a framework of how firm can sustain value creation was proposed. Finally, the implications of the proposed framework and future research directions were presented.

\section{The Value Creation}

Theories of the firm have been argued and developed to explain the existence of firms and their purposes. The Resource-Based View (RBV) for example, builds on the assumption that strategic resources are diversely distributed across firms. That is, only those firms with the capabilities to uniquely combine and configure specialised (scare, valuable, difficult to copy, and not easily traded) resources that can create value (Barney, 1991). This is because the services rendered by these unique bundle of resources and capabilities may lead firm to the creation of value (Amit and Zott, 2001).

The transaction cost theory of the firm emphasises cost minimisation and maximisation of efficiency in the production of products to create value. At the core of the theory is the choice of the most efficient governance form given a transaction that is embedded in a specific economic context - internalisation (Amit and Zott, 2001). For the theory, firm creates value by opting for transaction costs that offer minimal cost at the highest possible efficiency in the delivery of products. Thus, firms that economise on transaction costs could be expected to attract more value from transactions (Amit and Zott, 2001) to create value. 
But Slater (1997), complementing the Woodruff's (1997) argument for firms to develop and implement superior customer value strategies in the 21st century, argued that the focus of business activities is the customer value. That is, firm does not exist to reduce transaction costs or maximise profit alone. Rather, they exist to provide products because it is neither efficient nor effective for buyers to attempt to satisfy all their needs themselves. So, firms create value by delivery superior product offerings which lead to customer satisfaction.

Though not exhaustive, other scholars' perception of value creation includes - Table 1.

Table 1: Value Creation

\begin{tabular}{|l|l|}
\hline Author(s) & Value creation. \\
\hline Groth et al. (1996) & $\begin{array}{l}\text { Ensuring customer satisfaction in the market for products and receiving attractive } \\
\text { economic returns from customers. }\end{array}$ \\
\hline Bowman and Ambrosini (2000) & $\begin{array}{l}\text { When sales are achieved and customers view that the product confers more } \\
\text { consumer surplus better than competing alternatives. }\end{array}$ \\
\hline Sirmon et al. (2007) & $\begin{array}{l}\text { Firms' ability to provide solutions to the customers' needs while maintaining or } \\
\text { improving its profit margin. }\end{array}$ \\
\hline Lepak et al. (2007) & $\begin{array}{l}\text { Firms' ability to translate subjective value of the customers into customers' } \\
\text { willingness to exchange monetary amount for the value received. }\end{array}$ \\
\hline O'Cass and Ngo (2011) & $\begin{array}{l}\text { Firms' ability to respond to the values customers are looking for at the point of } \\
\text { proposition. The value customers are looking for include superior performance, } \\
\text { price, relationship and co-creation. }\end{array}$ \\
\hline Bhatti et al. (2011) & \begin{tabular}{l} 
The creation of lower cost of products compare to competitive alternatives. \\
\hline
\end{tabular}
\end{tabular}

Critical to these conceptualisations of firms' value creation is the customers as the target of value creation. But the concept of value creation is multidimensional, and it will be disservice to this paper and readers by making the customers the exclusive target of value creation. That is, firms exist to create value for customers only. It is not. This is because there are other firm stakeholders like employees, government, suppliers, complementors, competitors, communities and shareholders who have expectations of the firms. Yet, the customers remain strategic as the products offered by firms are expected to meet their expectations, which in turn mean optimization of profit or increasing returns for firms (Bowman and Ambrosini, 2007). This can best be understood if one imagines the nonexistence of the customers, then the survival of firms in the very beginning is at threat. And based on this perspective and the purpose of this research, customers become the target of firms' value creation.

Customers' satisfaction cannot be 100 per cent as they can be unreasonable (Spender, 2006). This is because customer taste and market have become even more stringent, sophisticated and dynamic, making it more difficult for firms to gain or retain customer loyalty. These market conditions are premised on the complexity and multidimensional alternatives in terms of product offerings that are available to the customers.

As new ideas fade as quickly as possible due to the intense competitions, firms are consistently challenged to harness their resources and capabilities to meet these needs satisfactorily. Particularly, firms need to anticipate, capture and analyse these expectations and transform these into a bundle of value deliverables in the form of products and relational advantage (O'Cass and Ngo, 2011). Thus, value creation is the process by which firms anticipate, integrate, and configure its resources and capabilities to create product offerings that meet or exceed customer expectations and generate better economic returns other than competing alternatives from other firms.

\section{The Customer Expectations And Knowledge Of Customer Expectations (Kce).}

Customer expectations are viewed as desires or wants of consumers. That is, what the customers feel a product should offer rather than would offer (Parasuraman, Zeithaml, and Berry, 1988). These expectations are the pre-consumption beliefs that consumers draw upon as the probability of occurrence of positive and negative events (Gilbert and Wong, 2003). It is the pretrial beliefs about a good or service that serves as standards or reference points against which good or service performance is judged (Zeithaml, Berry and Parasuraman, 1993).

In other words, it is the perceived-value customers that are sought from the purchase of a product. This "perceived-value" is the trade-off between what the customer receives (for example, quality, benefits, worth, utilities, surplus) and what the customers gave up to acquire and use a product - for example, price (Woodruff, 1997).

In making a purchase decision, customers look out for certain attributes in a products offering. These attributes are pre-conceived as they occur before purchase. As a pre-trial or pre-consumption beliefs or standard of performance reference judgement, these expectations are formed with the aid of information sources like prior exposure to the products, word of mouth, expert opinions, advertisement, as well as prior exposure to competitive product (Zeithaml, Berry and Parasuraman, 1993). And through an evaluation of products' performance, customers form what is called "confirmatory or disconfirmatory judgement". The customers' judgements of satisfaction or dissatisfaction result from the process of confirming or disconfirming their prior expectations (Arambewela, 2003). The general consensus however is that customers equipped themselves with 
pre-conceived desired attributes of a product or service. These attributes (expectations) are then compared with what is given (perceived attributes) to form judgement - a positive or negative of the products offering. The gap between the customer expectations and perceived product or service performance is the degree of satisfaction or dissatisfaction.

Customer satisfaction/dissatisfaction (CS/D) literatures have continuously established strong relationship between customer expectations and customer satisfactions. While customer expectations are preconsumption process, the latter is often a post-consumption one. The disconfirmation paradigm holds that customers compare perceived product performance to expectations. Performance that exceeds expectations is positively disconfirmed, performance that meets expectations is confirmed; and performance that falls short of expectation is negatively disconfirmed (Bolton and Drew, 1991). The more negatively the disconfirmation, the greater the dissatisfaction, whereas the more positive the disconfirmation, the greater the satisfaction. For example, Fornell et al.'s (1996) study of American Customer Satisfaction Index (ACSI) revealed that customer expectations naturally have a direct and positive association with a cumulative evaluation of firm performance customer satisfaction. Therefore, as earlier established, meeting or exceeding these expectations leads to creation of value and this can help firm cements its relationship with customers to gain customer loyalty and retention.

As customers compare perceptions with expectations when judging a firm's product offerings, understanding these expectations is a prerequisite for delivering superior product performance since customer perceptions of value are based on what is received and what is given (Parasuraman et al., 1991). Just as how firms scan the market to understand and offer products that can fulfill customers' needs, so do customers scan the market for products that can give them the largest consumer surplus (Bowman and Ambrossini, 2000). But when customers scan the market, what do they expect from product offerings they eventually settled for?

Empirical researches, especially in the areas of CS/D and customer service expectations, have provided important insights into customer expectations. Studies by Parasuraman et al. (1991), Slater and Narver (1994), Slater (1997), Rust et al. (1999) and Langrugues et al. (2011) revealed that customers are seeking products that offer superior value - an ever-increasing level of quality at reasonable cost. That is, the product offerings must be ready to deliver better value to customers or establish comparable worth at a lower cost or perform both (Bhatti et al., 2011). For example, the remarkable growth of Hewlett Packard (HP) in computer technology over the years has often been associated with the firm's continue capabilities in service excellence in customer satisfaction.

In Parasuraman et al.'s (1985) study to identify and measure service-quality dimensions, they suggested that customers evaluate overall service quality on five underlying dimensions. These dimensions include tangibility, reliability, responsiveness, assurance and empathy. Also, in consistent with Parasuraman et al.'s prior exploratory research, Bolton and Drew (1991) developed a multistage model of customers' assessment of service quality and value of residential customer and telephone service. It was revealed that a key determinant of overall service quality is the gap between performance and expectations (disconfirmation). The findings revealed further that customers want reliability and responsiveness.

Sonne's (1999) study of customer satisfaction in the Norwegian Institute of Fisheries and Aquaculture found that repeated purchases and loyalty (source of competitive advantage) were influenced by hard qualities that is, perceived competence of consultant and technical reliability demonstrated by the consultant in the performance of projects. The customers desire competency, reliability, tangibility as well as courtesies. By drawing comparison of consumers' product quality perceptions and expectations from garden centres in North Carolina, Hudson et al.'s (1997) found that though, there was a degree of variation in the degree of product perception and expectations, consumer demands empathy, responsiveness, reliability and the least, tan gibility.

And in Lim and Tang 's (2000) study of patients' expectations and satisfaction in Singapore's hospitals, they found that patients want improvement in tangibility, reliability, responsiveness, assurance, empathy, accessibility and affordability. At the heart of the patients expectation is assurance and responsiveness.

What is common among these empirical researches is that customers want something intrinsic. They want product they can be associated with; they want to be informed about the nature of the products; they want options and seamless relationships; they want superior and consistent performance, and safety. It is only by meeting these expectations can firm cements its relationship with the customers; increase their satisfaction and gain their loyalty and retention. Fig.1. below identified those key attributes customers expect from product offerings. 


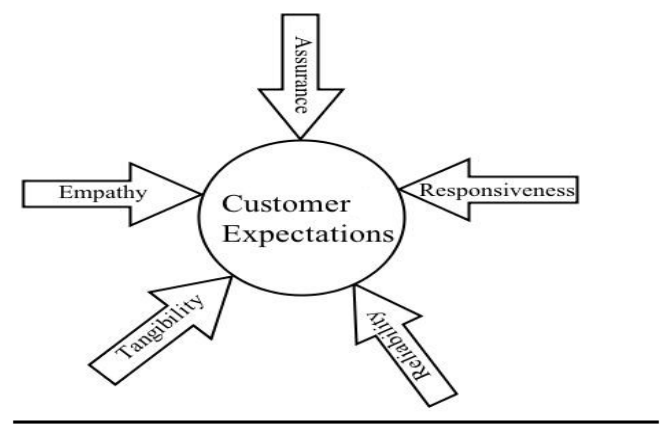

Figure 1: Customer Expectations

1. Reliability: Customers want firm to fulfill its promises. They often rely on what the firms claim a product offering is - performance. So, they expect that if a firm claims, for example, an add-on with a product, they expect that the firm should fulfill this add-on and be consistent about it. Thus, the ability of the firm to provide the customer what it actually promised, dependably and accurately is reliability. And by so doing, a firm has the potential to satisfy the customers.

2. Assurance: This resides in the firm's ability to convey trust and confidence to the customers that they are safe. For example, some firms give periodic and money-back guarantee as an assurance mechanism for their products to customers. With solid and strong assurance, a firm can instill in its customers trust and confidence.

3. Responsiveness: Sometimes, product contents may be of technical composition which means that the customers will require some form of assistance from the firm. They want the product offering to be troublefree and it meets their requirements. Thus the firm must be sensitive to these concerns; be aware of changes in their needs; and be speedy in the delivery. The firm can be responsive by willingly assist customers and providing them prompt service on usage of products or getting down with their services. For example, HP provides live online support and technical services for its customers. This allows the firm to respond, on a real-time, to customers challenges in product usage.

4. Empathy: Customers, like every human, are emotional and want to be valued and be treated specially. Beyond the purchase of a firm product, they want to be identified with the firm - its product and service. Empathy thus emphasises the ability of the firm to identify individual customers and be sensitive toward adapting its product to them. It is essentially the degree of care and attention a firm provide to the customers. Being empathetic towards the customers, a firm can build a long term bond with them. For example, customer service courtesies often constitute a great way by which firms can be effectively be empathetic towards its customers compare one firm whose customer service approach is poor.

5. Tangibility: Customers look out for product or service features that appeal to their physical sense. Though services may seem not to possess such physical characteristics, customers often turn to price and appearance of firm's personnel to form such physical sense. For tangible products, tangibility is the physical facilities, features and appearance.

Thus knowing what the customers expect is the first and possibly most critical step in delivering products that meet customer expectations and being wrong about it can have a severe impact on a firm's profitability - value creation. So, firms must engender effort to capture these expectations and design its product offerings in way that it will reflect these expectations. As customer expectations become the core of firm's business philosophy, the challenge for the firm will be to capture such knowledge of customer expectations (KCE) and translate these into product offerings of superior performance. Thus KCE becomes the core of firm's strategic resource.

\subsection{The Concept of Knowledge of Customer Expectations (KCE)}

Knowledge has been described as a processed data and information. It is the information possessed in the mind of individuals which (may or may not be new, unique, useful or accurate) relating to facts, procedures, concepts, interpretations, ideas, observation and judgement (Alavi and Leidner, 2001). Often, it is a product of raw data or information or observation that is subsequently transmuted into what Nonaka and Takeuchi (1995) describes as "justified true belief" that increases an entity's capacity for effective decision making. It involves 
the dynamic integration of experience, values, information and ideas that provide a framework for evaluating and incorporating new experience and information (Davenport and Prusak; 1988). And like Alavi and Leidner (2001) and Davenport and Prusak (1998), Gottschalk (2005) described knowledge as information combined with experience, context, interpretation, reflection, intuition, and creativity.

Nonaka and Konno (1998) further categorised knowledge into tacit and explicit knowledge. The tacit knowledge was described as individual perception of reality and vision for the future. This type of knowledge is not easily visible. It includes knowledge like intuitions, hunches and subjective insights. While the explicit knowledge is described as knowledge that can be readily transmit between individuals formally and systematically. These types of knowledge include scientific formulae, specification, manuals, and the likes.

However, for the firms, knowledge is embroiled in the whole gamut of its activities. That is, the collective sum of firm's human centred assets, intellectual property assets, infrastructure assets, and markets (Brooking, 1996). It is the firm's know-how - the firm's technological competences - these competences reflect individual skills and experiences as well as distinctive ways of doing things inside the firm (Teece, 1998). Ultimately, firm knowledge comprises the processes, products, rules, routines, culture, values, expertise, insights, intuitions, ideas, skills, technologies and experiences that are transformed into products for commercial end.

As knowledge becomes a key resource of the firms, the concept of knowledge of customer expectations (KCE) from this perspective could be describe as "what the firms know about the customers". It is the processed information relating facts, values, ideas, observation as well as judgement of customer expectations. It includes intuitions, hunches, subjective insights, scientific formulae, specification and manuals about the expectations of the customers. It is more like a strategic resource a firm can use to make effective decisions about the nature of customers' needs/expectations as well as increasing its productive and innovative capabilities. With KCE, a firm becomes more proactive in the process of designing and developing product offerings that can capture and meet customer expectations, and if possible, exceed them. Importantly, firms that are poised for success in this sternly competitive global market must evolve process by which such KCE is timely capture and translate into deliverables that lead to value creation.

\section{Value Creation And The Kce.}

Studies have however been carried out on how firms create and translate knowledge into innovative capabilities that enable them compete successfully in the global market (Cohen and Levinthal, 1990; Grant, 1996; Teece, 1998; Nonaka, 1994; Nonaka and Takeuchi, 1995; Lee and Lee, 2007). The consensus that a firm is an embodiment of knowledge is founded on the ground that every activity that is involved in the creation of value in the firm is knowledge dependent, and the primary role of the firms is the application of knowledge into the production of products.

Nelson and Winter (1982), for example, in their evolutionary theory of economic change, opined that the ability of firms to create superior performance is a function of the interaction of the explicit and tacit bodies of knowledge with economic realities and then stored in the routines available to future generation of employees. The firms integrate the explicit and tacit knowledge with its generic materials and culture to create superior performance in its product offerings. The absorptive capacity theory by Cohen and Levinthal (1990) also opined that the firms' value creation is a function of its ability to use prior knowledge to capture new ones, assimilate it and apply it to create innovative products.

The primary role of firms is the integration of the specialist knowledge residing in individuals through the creation, acquisition, storage and deployment of knowledge in the transformation of inputs into output (Grant, 1996). These activities according to Grant are supported by the recent firms' innovative trends around the world. Thus knowledge becomes the most important and most complex means of value creation. And value creation lies in the firm's capabilities to transform this knowledge into innovative product offerings.

Also, in arguing for the knowledge creating firms, Nonaka and Takeuchi (1995) and Nonaka and Konno (1998) developed the SECI model - Socialisation, Externalisation, Combination, and Internalisation.

Inherent in the is the dynamic and creative process by which both the tacit and explicit knowledge are captures, integrated, exchanged and transformed into firms' competitive capabilities (product offerings of superior performance). The model approach was noticed in the innovative process of Japanese firms like Toshiba and Sharp project teams. In the same vein, the study of 431 United States and European firms on what firms do with knowledge, Ruggle (1998) found that projects underway in these firms involve capturing, accessing and transferring knowledge that can lead to increased efficiency, as knowledge generation and application is critical to growth of the firms.

Competing effectively in the global markets, firms must develop the ability to use prior knowledge to recognise the value of new information, assimilate it, and apply it to create new knowledge and capabilities (Lee and Lee, 2007) as firms' performance is positively related to the process of how firms generate, access, facilitate, represent, use, and transfer knowledge within it. 
The point here is the reaffirmation of the firm as a repository of knowledge, and firms' value creation is dependent on the ability to capture knowledge, absorb it, combine it with existing one, and apply it to create product offerings of superior value for customers better than competing alternatives. As KCE becomes firms' strategic resource, it becomes imperative that firms first develop the capabilities to capture KCE by identifying, validating and communicating relevant information of what the customers want in terms of reliability, assurance, responsiveness, empathy, and tangibility and then translate them into product offerings of superior performance than any competing alternatives. Thus innovative abilities of the firms resides in the use existing knowledge within to capture new KCE, assimilate it, and then apply it to create new knowledge and capabilities - product offerings of superior performance (Cohen and Levinthal, 1990).

The challenge for firms however is capturing and translating KCE into product offerings of superior value. If value creation is the process by which firms anticipate, integrate, and configure its resources and capabilities to create product offerings that meet or exceed customer expectations and generate better economic returns other than competing alternatives. Thus the application of KCE becomes the central to firm's value creation. The effective assimilation and application of KCE could therefore distinguished innovative firms from less successful competitors (Trott, 2008). Yet, KCE may not be enough.

Doubtlessly, it is ambitiousness claiming theoretical contribution in the field as this paper portends. But extant literatures on contemporary innovative and the growing sophistication in customer tastes and preferences have necessitated the need for clarification of concepts - value creation and knowledge of customer expectations. More importantly, how better understanding of these expectations can help firms to create value. This paper therefore aims to provide a theoretical contribution to how firms create value by proposing a framework for sustaining value creation through the knowledge of customer expectations.

Firstly, the concept of value creation and knowledge of customer expectations were introduced. Then, the proposed "sustaining value creation through knowledge of customer expectations" framework is discussed by answering the following questions - what are the sources of Knowledge of customer expectations? How does the proposed framework works? And what are the contributions of the proposed framework?

The proposed framework (Fig. 2) illustrates something that could be called "sustaining value creation through KCE". The concept of sustaining value creation is not new and can be viewed from diverse perspectives. But because the target is the knowledge of customers expectations, the paper drew inferences from the theory of the knowledge creation and empirical researches from $C S / D$, then argues that sustaining value creation through the knowledge of customer expectations resides in the ability of firms to continuously anticipate, integrate and configure $\mathrm{KCE}$ to create product offerings that meet or exceed customer expectations better than competing alternatives.

The construct of the proposed framework is built on knowledge creation theory and customer expectations. Though, knowing what a customer expects (knowledge of customer expectations) of a product offering is a prerequisite to delivering value to a customer, yet do firms know how to sustain the process (so as to create competitive fit)? Where is the source of the knowledge of customer expectations? How can firms translate the knowledge of customer expectations into products offerings that can capture the value customers want? These questions no doubt are old but with the changing market roles of the customers, they deserve deeper understanding.

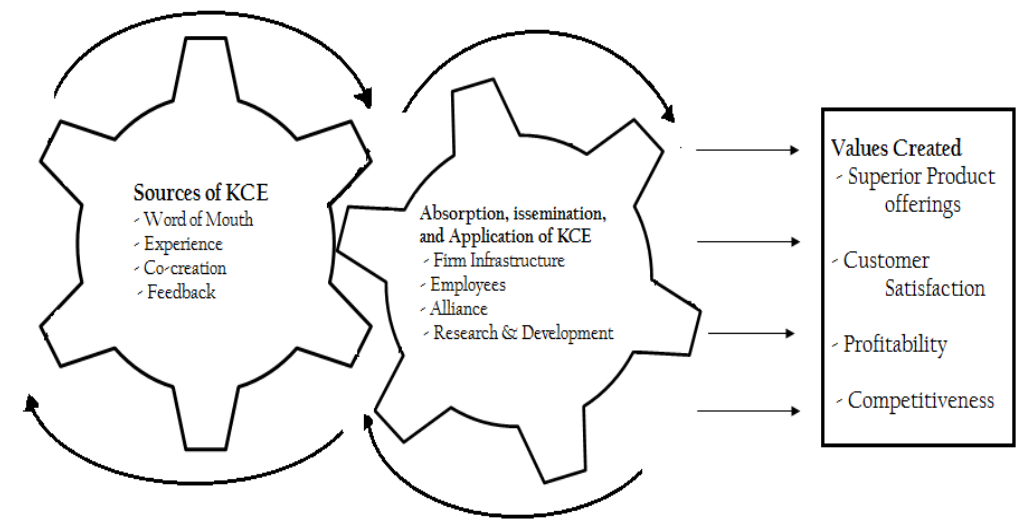

Figure 2: Sustaining Value Creation through KCE

Sustaining value creation through the knowledge of customer expectations in the proposed framework is not only a dynamic, a continuous process but as a reinforcing process of knowledge creation, renewal and application. It is a creative process of how firm can continuously be innovative by developing product offerings 
that reflect the customer expectations (value creation). Thus this paper argues that "sustaining value creation through the knowledge of customer expectations" is a synthesis of knowing and pre-empting process of customer expectations that drives value delivery not only to the customers but also to the firms.

\subsubsection{What are the sources of KCE}

Doubtlessly, KCE is firm-specific knowledge and the timely capture and creation of KCE can help firms develop the capabilities to tailor products to meet or exceed customer expectations. For example, it is common practice among firms like Dell Computer and HP to create pop-ups on their websites which allow customers to feed into their platform salient and valuable information about their tastes, preferences and challenges. This kind of information form a critical and latent knowledge that help these firms to continuously develop and deliver product offerings of innovative features that meet customer expectations. Though this is not exhaustive, firms can capture knowledge of customer expectations through:

4.1.1.1 Word-of-Mouth (WOM): The concept of WOM is the exchange of ephemeral oral or spoken messages between a contiguous source and a recipient would communicate directly in real (Buttle, 1998). It is usually spontaneous and borderless (positive or negative) and it disappears instantly as it is released. Generally research has support the claim that WOM is more influential on behavior than other means of marketer-controlled source.

It has shown that it influences a variety of conditions such as awareness, expectations, perceptions, attitudes, behavioural intentions and behaviour (Buttle, 1998). For example, Sheth (1971) contend that WOM is more important that advertising in raising awareness of innovation and securing the decision to try a product. With WOM, a firm can get a firsthand knowledge of customers' expectations and redesign its product or service to reflect such. For example, some stores have on-ground personnel who engage customers in one-to-one communication to get immediate knowledge of customers' perception of their product offerings. If well articulated, WOM provides viable platform for the firm to capture customer expectations and create KCE for the firm.

4.1.1.2 Co-creation: Doubtlessly, the evolving pattern of the global business environment has change the role of customers from the receivers of what the firms produce to source of firms' competence. Customers are stepping out of their traditional roles to become co-creators as well as consumers of value (Prahalad and Venkatram, 2000). They have become co-producer or according to Lengnick-Hall (1996) "partial employees" that provide vital input in the determining firm competence, product/service designing, testing and features. Cocreation is the process in which a firm allows customer to customize a host of products or services simply by choosing from a menu of features (Prahalad and Venkatram, 2000). That is, the customers is allows to determine the features and performance of a product offering. Dell Computer for example, created the "build-to-order" platform on its website that allows customers to design and create products of their tastes and preference.

This trend is influence by the informed and sophisticated nature of customers' knowledge of products and information technology (internet). With co-creation, a firm not only learns the dynamics nature of customers' tastes and preference, it enables the customers to take full advantage of all the potential benefits embedded in a product offering. Thus by allowing the customer direct or indirect opportunity to make input in product features and performance design, the firms create opportunity to create KCE for current and future capability.

4.1.1.3 Experience: Experience has been widely accepted to influence or shape customers' expectation in the study of customer satisfaction/dissatisfaction process. In Muller and Tse's (1991) investigation of whether postconsumption emotional responses can be traced to customer's expectation, performance, norms from previous experience, primary evaluation of the experience and the disconfirmation expectations. They revealed that customers' post-consumption experience can be trace to the point when of customers prepare for the consumption experience (pre-consumption experience). That is, the final decision to purchase a product or service is influenced by customers' pre-consumption experience. Experience is the emotional response to direct or indirect consumption of a product offering. The direct and indirect consumptions come in form of preconsumption and post consumption of product. The pre-consumption represents the customers cognitive formation of how the customer prepares for the consumption experience (Muller and Tse, 1991) while postconsumption is the emotional response after the consumption of a product. For example, the atmospheric condition of a store offers a would-be customer the opportunity to develop pre-consumption emotions towards a product or service.

As customers rely primarily on pre-consumption and post-consumption experience comparison standards (McGill and Lacobucci, 1992) as these experiences shape their satisfactory/ dissatisfactory standards, firms must also realise that customers are not prepared to accept experiences fabricated by companies. 
Increasingly, they want to shape those experiences themselves, both individually and with experts or other customers (Prahalad, and Venkatram, 2000).Thus firm can help customers to shape and develop pre-experience comparison standards rather than allowing the customers to construct evaluations after the fact (Muller and Tse, 1991; McGill and Lacobucci, 1992) by allowing them to exploit all their senses through the staging of activities and interactions. This process provides a platform for the firm to capture latent and salient issues of customers' expectations as these expectations can be shaped by customers' pre-consumption experiences.

4.1.1.4 Feedback: Generally, feedback is a post-consumption response of customers to a product offerings. It is through feedback customers get the opportunities to react (positively or negatively) to a firm product performance or service delivery. It gives the customers the chance to voice their frustrations. With the multidimensional alternatives available to customers to seek redress to their complains, firms have discovered that feedback systems are not just a mere platform to address customer complains. Rather, it is a system that promotes continuous learning and innovation. The customer feedback influences decisions on everything from where the firm will compete to product and service development, pricing, policies and processes (Markey, Reichheld and Dullweber, 2009). Importantly, through feedback firms get to understand what customers expect and it can then align its product offerings to reflect these expectations.

These sources of knowledge of customer expectation is critical to any firm delivery of value to the customer as it allows them to capture both expressed and latent customer expectations thereby developing superior solutions to these expectations.

\subsubsection{How does the proposed framework works?}

As firms capture and create KCE from the above sources, it must develop the ability to absorb and disseminate it across units or departments within it for use. $\mathrm{KCE}$ is largely unrefined or raw data that is going to require further transmutation before they can be use. Through the absorption and dissemination process, the firm gets to reconfigure existing information through sorting, adding, recategorising, and recontextualising of explicit and tacit knowledge that leads to the creation of new knowledge. The absorption process involves the intersection of the capability of the firm to exploit it knowledge and the unexplored potential of the technology and technological opportunities (Kogut and Zander, 1992). Dissemination on the other hands involves the distribution of the absorbed knowledge throughout the firm or value chain (Demerest, 1997). It is concern with the use of human process and technological infrastructure within and outside the firm to share the absorbed KCE to other units across the firm.

The processes (absorption and dissemination) are important in the sense that they represent the source of a firm absorptive capability (critical in firm's innovative capabilities). That is, the human processes and technical infrastructure that makes transmuted embodied knowledge available to the people within the firms that use it for innovative capability to do work for customers, suppliers, strategic partners and the firm itself. This process is what Nonaka, Takeuchi, Konno described as "creative dialogue" or "crystalisation." That is, where various subunits or department within a firm test the reality and applicability of concept created. From the framework, creative dialogue across the firm will occur through the cooperation and synergisation of the followings:

- Employ the support of firm technological infrastructure to harness the new knowledge with the existing ones;

- Tap into tacit knowledge of individual employees through dialogue (exchanging ideas); and creation of work groups that continuously analyse the new information with the existing ones;

- Research and development (R\&D) unit that connect the knowledge with testing and experimentation; and

- Collaborate with other firms (for example, suppliers) for strategic capability.

Importantly, the process helps a firm to leverage its existing knowledge (KCE ) to create new ones for further or future application which is critical in creating innovative products (value creation).

As new idea or approach is generated through firm's absorption and dissemination process (creative dialogue), the firm must apply it to capture the essence of its creation. The argument that knowledge is a critical resource in firm's competitive capability resides in the application of it. Firms cannot only capture, create, absorb and disseminate knowledge. Rather, it must further use it to create commercial value for its customers (Demarest, 1997) - the KCE must be translated into commercial benefits for the firm through the launching of a new product or an improved product (Trott, 2008). The application of KCE involves using the knowledge created from the transmuted KCE to solve customers' problems. This could mean upgrading existing product offerings with new performance features or the creation of an entirely new one. It is only this way that a firm can capture the benefits of the entire framework - creating value for the customers and the firm itself. 


\subsection{What are the contributions of the proposed framework?}

The proposed framework built on the theory of knowledge creation of the firm. The concept of knowledge is understood here from the purview of the knowledge of customer expectations. In agreement with Leidner and Alavi (2001), knowledge here is the information possessed in the mind of individual (customer) which relates to facts, procedures, concepts, interpretations, ideas, observations and judgement of what the customer expects of a product offering. Thus the paper incorporated these features of knowledge in the proposed framework.

The proposed framework considers knowledge of customer expectations as reinforcing in the creation value. This is similar to what Nonaka and Takeuchi (1995) described as "crystalisation" - leveraging existing knowledge to create new ones. Therefore, we argued that firms can sustain the value creation through knowledge of customer expectations as the proposed framework allows the firm to leverage existing knowledge with new inflow of knowledge of customer expectations to create new ideas or solutions (product offerings) to customer problems.

In the proposed framework, activities in it show the creative process of sustaining value creation. That is, the interactive relationship between capturing, absorbing, disseminating and applying knowledge of customer expectations to continuously create knowledge or solution for customers. These activities exemplified Demarest's (1997) and Leidner and Alavi's (2001) knowledge management framework which lend support to the framework suggested in the paper.

Lastly, the proposed framework is based on the contemporary roles of 21th century customers and their expectations in the global market. It reflects the importance of how the theory of the firm's value creation can benefit from building on this concept of knowledge of customer expectations. As argued by Woodruff (1997), Slater (199), and Prahalad and Venkatram (2000) that customer value is the focus of the 21th century business activities, this proposed framework could help in better understanding of the customer as a source of value to the firms.

\subsection{Implications of the proposed framework}

The proposed framework - sustaining value creation through knowledge of customer expectations, has several implications. Academics and researchers in the strategic management could give more attention to the role of the knowledge of customer expectations. Apart from widen firms' predictability of customers, it also bring to bear the contemporary recognition of the customers as sources of firms' competitiveness. The novelty is that, though employees form the reservoir of knowledge (tacit especially) for the firm, this framework has taken it beyond the boundary of the employees by incorporating customers.

The proposed framework replicates the social learning or the social knowledge creation paradigm. As firms operate in a social environment, comprising the network of customers, suppliers, employees, competitors and other members of the industry, the framework provides a platform in which firms can learn from these members and incorporate such learning approach in the firms' process of knowledge creation (product offerings). Basically, input from other members of the industry can further strength the sources of KCE as replicated in the proposed framework.

Knowledge according to Teece (1998) can be a source of firms' dynamic capabilities as it underpins firms' product offerings. With this, scholars can begin to shift attention to, importantly, KCE as a source of dynamic capability. This could help in understanding how customers' pre-emptive patterns affect firms' product offerings. Also, at the heart of firms' competitiveness is the ability to capture, understand and translate customer expectations into superior value for them. Our proposed framework describes how firms can capture these expectations and translate them into commercial value. Thus future research can examine how source(s) of KCE affects value creation of the firms. For example, an empirical research of the effect of co-creation on firms' value creation could provide better understanding of this proposed framework.

For academics and management practitioners, this paper provides the possibility to understand what constitute KCE and how firms can translate it into customer satisfaction which is critical to sustaining competitive advantage.

\section{Conclusion}

The emerging pattern of information technology and globalisation is re-inventing the roles of the customers in the global market and scholars and managers must respond to the transformation. Thus, competing successful in this market means that firms must recognise these new roles and develop product offerings that deeply capture them. Importantly, the more a firm knows about a customer the easier it is to deliver product offerings of greater-experience leading to the creation of value.

The challenge, however, for firms is not only to create value for the customers at a point in time. The firm needs to strategically sustain the process in order to continuously deliver product offerings of superior performance. In this paper, the proposed framework describes how firms can sustain value creation through 
timely capturing of knowledge of customer expectations. The beauty of the proposed framework is that it facilitates overlapping product development cycles. This is because as new KCE comes in, it allows firms to quickly transform such knowledge into performance and features of the next product offerings. The belief is that a firm that replicate the process can develop the capability to sustain the value creation process and compete successfully in the global market.

\section{Reference}

[1] Slater, F. S. and Narver, J. C., "Marketing Orientation, Customer Value, and Superior Performance", Business Horizons, Vol. 32 (2), 1994, $22-28$.

[2] Woodruff, R. B., "Customer Value: The next source Competitive Advantage", Academy of Marketing Science Journal, Vol. 25 (2), $1997,139-153$

[3] Slater, F. S., "Developing a Customer Value-Based Theory of the Firm", Academy of Marketing Science Journal, Vol. 22 (2), 1997, $162-167$.

[4] Prahalad, C. k. and Venkatram, R., “Co-opting Customer Competence”, Harvard Business Review, Vol. 78 (1), 2000, 79 - 86.

[5] Barney, J., "Firm Resources and Sustained Competitive Advantage", Journal of Management, Vol. 17 (1), 1991, 99 -120.

[6] Amit, R. and Zott, C., "Value Creation in E-Business", Strategic Management Journal, Vol. 22, 2001, 493 - 520

[7] Groth, J. C., Byers, S. S. and Bogert, J. D., "Capital, Economic Returns and the Creation of Value”, Management Decision, Vol. 34 (6), 1996, $21-30$.

[8] Bowman, C. and Ambrosini, V., "Value Creation versus Value Capture: Towards a Coherent Definition of Value Strategy", British Journal of Management, Vol. 11 (1), 2000, 1 - 15.

[9] Simon, D. G., Hill, M. A., and Ireland, R. D., "Managing Firm Resources in Dynamics Environments to Create Value: Looking Inside the Black Box", Academy of Management Review, Vol. 32 (1), 2007, 273 -292.

[10] Lepak, D. P., Smith, K. G. and Taylor, M. S., "Value Creation and Value Capture: A Multilevel Perspective", Academy of Management Review, Vol. 32 (1), 2007, 180 - 194.

[11] O'Cass, A. and Ngo, L. V., "Examining the Firm's Value Creation Process: A Management Perspective of Firm's Value Offering Strategy and Performance", British Journal of Management, Vol. 22 (4), 2010, 646 - 671.

[12] Bhatti, W. A., Khan, M. O., Ahmad, A., Hussain, N., and Rehman, K., "Sustaining Competitive Advantage through Effective Knowledge Management", African Journal of Business Management, Vol. 5 (6), 2011, 3297 - 3301

[13] Bowman, C. and Ambrosini, V., "Firm Value Creation and Levels of Strategy", Management Decision, Vol. 45 (3), 2007,360 371.

[14] Spender, J. C., "Getting Value from, Knowledge Management”, The TQM Magazine, Vol. 18 (3), 2006, 238 - 254.

[15] Parasuraman, A., Zeithmanl, V. A. and Berry, L. L., "SERVQUAL: A Multiple - item Scale for Measuring Consumer Perceptions of Service Quality", Journal of Retailing, Vol. 64, 1988, 12 - 40.

[16] Gilbert, D. and Wong, R. K. C., "Passenger Expectations and Airline Services: A Hong Kong Based Study", Tourism Management, Vol. 24, 2003, $519-532$.

[17] Zeithaml, V. A., Berry, L. L. and Parasuraman, A., "The Nature and Determinants of Customer Expectations of Service", Journal of Academy of Marketing Science, Vol. 21 (1), 1993, $1-21$

[18] Arambewela, R. "Post-choice Satisfaction of International Postgraduate Student from Asia Studying in Victoria Universities", Unpublished doctoral thesis, Victoria University, Melbourne, Australia, 2003.

[19] Bolton, R. N. and Drew, J. H., "A Multistage Model of Customers' Assessments of Service Quality and Value", Journal of Consumer Research, Vol. 17(4), 1991, 375 -384.

[20] Fornell, C., Johnson, M. D., Anderson, E. W., Cha, J. and Bryant, B. E., "The American Customer Satisfaction Index: Nature, Purpose, and Findings", Journal of Marketing, Vol. 60 (4), 1996, 7 - 18

[21] Parasuraman, A., Berry, L. L. and Zeithmanl, V. A., "Understanding Customer Expectations of Service", SLOAN Management Review, Vol. 32 (2), 1991, $39-48$.

[22] Rust, R. T., Inman, J. J., Jia, J., and Zahorik, A., "What You Don't Know About Customer-Percieved Quality: The Role of Customer Expectation Distributions", Marketing Science, Vol. 118 (1), 1999, 77 - 92.

[23] Landroguez, M. S., Castro, B. C., and Cepeda-Carrion, G., "Creating Dynamic Capabilities to Increase Customer Value", Management Decision, Vol. 49 (7), 2011, 1141 - 1159.

[24] Parasuraman, A., Zeithmanl, V. A. and Berry, L. L., "A Conceptual Model of Service Quality and its Implications for Future Research", Journal of Marketing, Vol. 49, 1985, $41-50$.

[25] Sonne, A., "Determinant of Customer Satisfaction with Professional Services - A study of Consultancy Services", Oekonomisk Fiskeriforskning, Vol. 9 (2), 1999, $97-107$.

[26] Hudson, J. T., Behe, B. K., Ponder, H. G. and Barrick, W. E., "Consumer Perceptions and Expectations of Garden Center Product and Service Quality", Journal of Environmental Horticulture, Vol. 15 (1), 1997, 12 - 15.

[27] Lim, P. C., and Tang, N. K. H., "A Study of Patients' Expectations and Satisfaction in Singapore Hospitals', International Journal of Health Care Quality Assurance, Vol. 13 (7), 2000, 290 - 299.

[28] Alavi, M. and Leidner, D. E., "Review: Knowledge Management and Knowledge Management Systems: Conceptual Foundations and Research Issues", MIS Quarterly, Vol. 25 (1), 2001, 107 - 136.

[29] Nonaka, I. and Takeuchi, H., The Knowledge Creating Company, New York: Oxford University Press, 1995.

[30] Davenport, T. H., and prusak, L. Working Knowledge, Harvard Business School Press, Boston, 1998.

[31] Gottshalk, P., Strategic Knowledge Management Technology, Hershey: Idea Group Publishing, 2005.

[32] Nonaka, I. and Konno, N., "The Concept of "Ba": Building a Foundation for Knowledge Creation", California Management Review, Vol. 40 (3), 1998, $40-54$

[33] Brookings, A., Intellectual Capital: Core Asset for the Third Millennium, London, UK: International Thomson Business Press, 1996.

[34] Teece, D. J., "Capturing Value from Knowledge Assets: The New Economy, Markets for Know-How, and Intangible Assets", California Management Review, Vol. 40 (3), 1998, 55 - 79.

[35] Cohen, W. M. and Levinthal, D. A. (1990), "Absorptive Capacity: A New Perspective on Learning and Innovation", Administrative Science Quarterly, Vol. 35 (1), 1998, 128 - 152.

[36] Grant, R. M., “Toward A Knowledge-Based Theory of the Firm”, Strategic Management Journal, Vol. 17(Winter Special Issue), $1996,109-122$. 
[37] Nonaka, I., “A Dynamic Theory of Organisational Knowledge Creation”, Organisation Science, Vol. 5 (1), 1994,14 - 37.

[38] Lee, Y. and Lee, S., "Capabilities, Processes and Performances of Knowledge Management: A Structural Approach", Human Factors and Ergonomics in Manufacturing, Vol. 17 (1), 2007, 21 - 41.

[39] Nelson, R. R., and S. Winter., An Evolutionary Theory of Economic Change, Cambridge MA: The Belknap Press. Cambridge MA, 1982 .

[40] Ruggles, R., “Knowledge Management in Practice”, California Management Review, Vol. 40 (3), 1998,80 - 89.

[41] Troth, P., Innovation Management and New Product Development, $4^{\text {th }}$ Ed., Harlow: Pearson Education, 2008.

[42] Buttle, F. A., "Word of Mouth: Understanding and Managing Referral Marketing", Journal of Strategic Marketing, Vol. 6, 241 254.

[43] Sheth, J. N., "Word-of-Mouth Low-Risk Innovation”, Journal of Advertising Research, Vol. 11 (June), 1971,15 -18.

[44] Lengnick-Hall, C. A., "Customer Contributions to Quality: A different view of the Customer-Oriented Firm", Academy of Management Review, Vol. 21 (3), 1996, 791 - 821.

[45] Muller, T.E. and Tse, D. K., "Post-Consumption Emotions: Exploring their Emergence and Determinants", Journal of Consumer Satisfaction, Dissatisfaction and Complaining Behaviour, Vol. 4, 1991, 13 - 20.

[46] McGill, A. L. and Lacobucci, D., "The Role of Post-Experience Comparison Standards in the Evaluation of Unfamiliar Services", Advances in Consumer Research, Vol. 19, 1992, 570 - 578.

[47] Markey, R., Reichheld, F., and Dullerweber, A., "Closing the Customer Feedback Loop", Harvard Business Review, Vol. 87 (12), $2009,43-47$.

[48] Kogut, B. and Zander, U., "Knowledge of the Firm, Combinative Capabilities, and the Replication of Technology", Organisation Science, Vol. 3 (3), 1992, 383 - 397.

[49] Demarest, M., "Knowledge Management: An Introduction”, Long Range Planning, Vol. 30 (3), 1997, 374-384

[50] Boulding, N., Karla, A., Staelin, R. and Zeithmanl, V. A., "A Dynamic Process Model of Service Quality: From Expectations to Behavioural Intentions”, Journal of Marketing Research, Vol. 30, 1993, 7 - 27.

[51] Johnson, M. D. and Fornell, C., "A Framework for Comparing Customer Satisfaction across Individuals and Product Categories" Journal of Economic Psychology, Vol. 12, 1991, 267 - 286.

[52] Kakabadse, N. K., Kouzmin, A. and Kakabadse, A., "From Tacit Knowledge to Knowledge Management: Leveraging Invisible Assets", Knowledge and Process Management, Vol. 8 (3), 2001, 137 - 154.

[53] McCollough, M. A., Berry, L. L., and Yasdav, M. S., “An empirical Investigation of Customer Satisfaction After Service Failure and Recovery”, Journal of Service Research, Vol. 3 (2), 2000, 121 - 137.

[54] Sheth, J. N. and Mittal, B., "A Framework for Managing Customer Expectations", Journal of Marketing Focused Management, Vol. $1,1996,137-158$.

[55] Spender, J. C., "Making Knowledge the Basis of a Dynamic Theory of the Firm”, Strategic Management Journal, Vol. 17 (Winter Special Issue), 1996, $45-62$.

[56] Zeithaml, V. A., Rust, R. T. and Lemon, K. N., "The Customer Pyramid: Creating and Serving Profitable Customers", California Management Review, Vol. 43 (4), 2001, 118 - 135 